\title{
Identity Politics of Papuan Indigenous Ethnics in the Position Seizure Contestation: A Case Study of the OPD Structural Positions in the Governmental Bureaucracy in Papua
}

\author{
Ferinandus Leonardo Snanfi Universitas Gadjah Mada, Indonesia \\ Muhadjir Darwin Universitas Gadjah Mada, Indonesia \\ Setiadi Universitas Gadjah Mada, Indonesia \\ Hakimul Ikhwan Universitas Gadjah Mada, Indonesia
}

\begin{abstract}
This research was aimed to (1) Know how identity politics of Papua indigenious ethnics of Papua contested to seize structural positions of the OPD (Regional Apparatus Organization) in the governmental organization (2) Know identity politics of Papua indigenous ethnics collaborated with identity politics of non-Papuan ethnics in filling structural position of the OPD in the governmental bureaucracy. The research method used was qualitative i.e. describe, record, analyze, interpret conditions occur today. While data gathering used an observation technique, photos and also interview technique. The research results showed (1) Identity politics practice implemented in the governmental bureaucracy shown along with the existence of dominance of office chief, secretary, structural position and also office with much financial were mostly dominated by MT ethnics. MT ethnics marginalized other Papuan ethnics in positions of office chief, agency, district, secretary, structural position. From the process of marginalized Papuan ethnics were affected by ethnics egoism from village, clans, family, one ethnic and other Papuan ethnics emerge other Papuan ethnics prefer non-Papuan ethnics to collaborate in power in the governmental bureaucrcy. Various powers in the filling of the OPD structural positions in the governmental bureaucracy. The bureaucracy of Papuan governmental bureaucracy was still thick with a cultural primordial, familism, tribalism and margaism. The purpose of ethnics identity politics applied in the governmental bureaucracy include to dominate economic resources that are much such as: Otsus Fund, APBD, PAD, DAK, DAU, governmental projects and programs for self ethnic interest and political groups in the governmental bureaucracy. (2) The filling of the OPD structural position of the governmental bureaucracy. The whole of position percentage data result available in filling the OPD structural position of the governmental bureaucracy, MT ethnics dominate all of positions available. And is followed by non-Papuan ethnics (BS, BN, MR, AN, and TA) that collaborated with MT ethnics in seizing number one and number two chairs in the governmental bureaucracy. Team baperjakat has selected officers who are skilled, good career, professional suitable with country's civil apparatus. However, all decision to promote officials in the OPD structural position, that guard ethnic contestation in the governmental bureaucracy, in overall policy based on number one and number two persons in the governmental bureaucracy. The purpose of collaboration was to dominate jointly economics resources that are much in the governemntal bureaucracy such as: Otsus Fund, APBD, PAD, DAK, DAU, governmental projects and programs for ther ethnic's interest and their politics group interest.
\end{abstract}

Keywords:

Political Identity; Papua; Structural Position

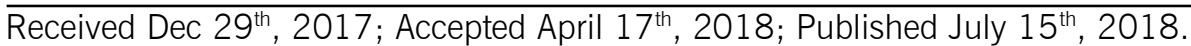




\section{INTRODUCTION}

Central government's objective in issuing special autonomy policy in Papua and West Papua province is for all indigenous ethnics in Papua can cooperate to build their own region accordingly to the Papua reality (Reba et al, 2015). Therefore, the development acceleration is achieved for all Papuans. For example, the special autonomy could create acceleration in people economical co ndition, human resources

Ferinandus Leonardo Snanfi is a doctoral student at Policy Studies-Universitas Gadjah Mada, Gedung Masri Singarimbun, JI. Tevesia, Bulaksumur, Kabupaten Sleman, Daerah Istimewa Yogyakarta Indonesia. His research interest about beureucracy and politics in Papua. (ferisnanfi@yahoo.com).

Muhadjir Darwin is a professor at Doctoral Programe of Policy Studies-Universitas Gadjah Mada, Gedung Masri Singarimbun, JI. Tevesia, Bulaksumur, Kabupaten Sleman, Daerah Istimewa Yogyakarta Indonesia. His research interest about population, leadership and policy. (muhadjir.darwin@gmail.com).

Setiadi is a lecturer and researcher at Doctoral Programe of Policy Studies-Universitas Gadjah Mada, Gd. R. Soegondo It. 5 FIB UGM JI. Sosiohumaniora No. 1 Bulaksumur, Kabupaten Sleman, Daerah Istimewa Yogyakarta Indonesia. His research interest about poverty reduction and international

(setiadi_antro@ugm.ac.id).

Hakimul Ikhwan is a lecturer at Doctoral Programe of Policy Studies-Universitas Gadjah Mada, JI. Sosio-Justisia No.2 Bulaksumur Indonesia. His research interest about multiculturalism, social policy and politics. (hakimulikhwan@ugm.ac.id).

The previous version of this paper has been presented in International Symposium on Indonesian Politics in Universitas Negeri Semarang-Indonesia April 2018. We would like to thank to participants of the symposium for the comments, and two anonymous reviewers for their comments. development, governmental institution development, and political education for the people.

However, this objective is being hampered by the fact that Papuan ethnics are more focused in political issues than other aspects in special autonomy or SA (otonomi khusus in Bahasa, or commonly abbreviated as otsus). The facts show that primordial issue is overshadowing social and economic issues that focus on human resources. One of the concrete evidences of such reality is that the identity politics is used and is reproduced by certain groups to reach their political goals. It is the very sphere where Papuans play their identity politics. Identity is a dynamic concept that integrates common features in diversity that identically related and its identity identification (Mayer, 2015).

To reach such identity political goal, Papuans exploit it in their daily life. However, in running the identity politics, Papuans also exploit the non-Papuan ethnic identities that leads to identity political game constellation in local political contestation (Ruhyanto, 2016). It is interesting to research how diverse ethnicity in Papua play their identity politics. It is also important to see how Papuans build relation among themselves 
when they interact with non-Papuan ethnics. Also noteworthy, how identity politics is utilized in achieving personal goals, in this case, Organisasi Perangkat Daerah/OPD (Local Government Agencies Organization).

The phenomenon that is happening is that indigenous Papuan ethnics are competing between themselves for power and marginalize other indigenous Papuan ethnics. Within local political contestation to seize the power, ethnic identity is prominently used as the means to connect solidarity, cognitive, moral, and emotional bonds between individuals and groups (Klinken, 2007). Identity politics, according to Klanderman (2015), is "When someone is thoroughly involved in political protest process in the name of his/her group, then, he/she will exploit all of the group's identity to be the struggle focus in order to seize the power".

Thus, the political elites exploit the unity of indigenous Papuan ethnics in order to hold control over economic resources such as dana otsus (Special Autonomy Fund), Pendapatan As/i Daerah/PAD (Own-source Revenue), Dana Alokasi Umum/DAU (Special Allocation Fund), and other projects within the scope of governmental bureaucracy positions (Arie and IImar,
2017). The top seat in governmental bureaucracy can only be obtained by capturing the majority of people's vote in pilkadalpemilihan kepala daerah (local executive election). Huntington (1995) explained that democracy is institutional management to reach political decision by competing over people's vote to seize the power.

Non-Papuan ethnics namely BS, BN, $M R, \quad A N$, and TA are also playing important role in local politics. Portion of power that is offered to $B S, B N, M R, A N$, and TA ethnics is to control second positions under the highest position of local bureaucracy so they can have dominant access to dana otsus, PAD, and DAU. Beside those resources, the private sectors are also being dominated by BS, BN, MR, AN, TA in local politics constellation. However, BS, BN, MR, AN, TA ethnics do not bring identity attributes as their means to take part in local politics because they do politics in a more relaxed. From this situation, political lobbies emerge from MT and MI ethnics to cooperate with $\mathrm{BS}, \mathrm{BN}, \mathrm{MR}, \mathrm{AN}$, and TA ethnics who have the largest number of populations. The political deal between the two sides is not formally done to fill the structural positions in government bureaucracy. However, BS, BN, MR, AN, 
and TA ethnics do not give their support to $\mathrm{MI}$ but rather to give it to MT ethnic instead in order to hold the highest leadership in the region.

The impact of local ethnic identity politics has been more evident in government bureaucracy (Hong, 2016). For example, the competition over structural local government organizations, both strategic and not strategic ones, and further, the corruptive, collusive, and nepotistic behavior. There are also emerging behaviors such as spoils system, patrimonial relationship, and other negative acts in government bureaucracy. Based on aforementioned description, the researchers are interested to analyze ethnic politics behavior in government bureaucracy. Hence, this paper answered these questions (1). Indigenous Papuan ethnic identity politics is contesting for structural local government's positions in the bureaucracy. (2) Indigenous Papuan ethnic identity politics collaborate with non-Papuan ethnics in assigning structural positions of local government organization in bureaucracy.

\section{RESEARCH METHOD}

The research type is qualitative method. Nasir (1988) explained, qualitative research is a research to make description on a situation or an event. Then, Mardalis (1990) explained this kind of method aims to describe, record, analysis, and interpret events that happen now. According to Singarimbun and Effendi (1995), descriptive research intends to measure accurately certain social phenomenon. The goal of descriptive research according to Irawan (2002) is to describe or explain something as it is so that the researcher can get clear description on situations on the field as naturally as possible. And then, Mantra (2004) said that descriptive research is a method in investigating the status of a group of people, an object, a set of condition, a system of thought, and events in current time. Descriptive research aims to describe or to portray complex social reality within the society.

Descriptive research yields qualitative data. According to Sugiyono (2007), descriptive research is a research that is carried out on other variable. Categorized in qualitative data are words, sentences, schemes, and pictures. In addition, Moleong (1997) explained that qualitative research has characteristics that an individual is as the research tool, the analysis is inductive and descriptive in nature, emphasizes on temporary 
research design, and research result is times to get informant's whole and agreed upon as research subject. complete perspective. This technique Research that uses qualitative procedure aims to get accountable data. The method is common in social research that information the researcher looks for in this attempts to interpret descriptively on technique is the opinion of several meanings of phenomenon in social community leader and community context. Besides that, this research member whom are considered method is chosen in order to give knowledgeable on the issue of the something useful and positive.

For the sake of representative, research. In this method, the interview accurate, and accountable data and to characteristic is not formal but rather to spontaneous interviews. This spontaneous answer the research question, this research uses purposive informant (Arikunto 1998). According to Sugiyono (2007), purposive informant is selected informant as the research subject according to his/her expertise or certain purpose instead of stratified or cluster randomness. Nawawi (2001) emphasized that informant should matches to certain criteria that are set in accordance to research objective.

The most important step in this research is the data collection technique because the main goal of research is to obtain data. By using the proper data collection technique, the scientific research standard can be fulfilled. The data collection techniques in this research are as follows. First, in-depth interview is intended to get data through direct characteristic makes this method is more objective and valid since there is no engineering by the researcher (Salim, 2006). This research utilizes in-depth interview since it emphasizes on familiarity by asking the openly ask the questions in flexible manner. Second, secondary data is data that has been previously processed and is owned by institutions that allow researchers not to replicate the exact research. Secondary data or supporting data is documentation from informant, or other supporting evidences from the field of research. Documentation method is useful for examining historical data. The majority of historical data are in form of letters, pictures, photographs, memorabilia, report, or other literature related to the research subject.

communication that takes place several 


\section{LITERATURE REVIEW}

\section{Research Novelty}

This research is different from other previously conducted within the same topic. Suwae, et.al (2011) in their findings explained that every ethnic groups in Papua have their own ethnocentrism in their leadership. And then, Lefaan (2012) in the dissertation research mentioned that, special autonomy gives discretion to have selfdetermination based on ethnicity sentiment and primordial bonds. Hapsari (2011) research showed there is sons of soil domination in bureaucratic positions in the region that other people from the outside (non-Papuan) are eliminated from the primordial bonds political contestation. Laksono (2001) explained that Special Autonomy Law had been deepening the primordial bonds or ethnocentrism between the indigenous Papuans. Kubangun (2014) confirmed this that the contestation between indigenous Papuan bonded them in the bureaucracy structure based on primordial identity was getting stronger.

Based on those researches, this article's researchers can assert the uniqueness of this research. This article's research novelty is that it studies Papua's special autonomy eventually created indigenous Papuan ethnic identity politics in government bureaucracy. Such ethnic identity political contestation leads other Papuan ethnics to be marginalized in positions such as head of local government organizations, secretaries, structural positions, and dominated the local government organizations structural positions in government bureaucracy. The marginalization is influenced by ethnic egoism from village, clan, family, and to others Papuan ethnic. This situation encourages other Papuan ethnics to prefer non-Papuan ethnic to collaborate in seizing power and in power sharing in government bureaucracy organizations structural positions. The goal of employing indigenous Papuan ethnic identity in government bureaucracy is to have control over abundant economic resources such as Dana Otsus, APBD, PAD, DAK, DAU, projects, and government programs for their own ethnic and ethnic political group benefit.

\section{RESULT AND DISCUSSION Ethnic Identity Politics Manifestation}

Ethnical identity bond manifest in group of people with their own primordial features such as level, pride, language, custom, and belief that is imposed to each member born in the group. This 
makes a group to have similarities with other group. The embedded formal form. characteristics in an ethnic group is a growing sense of community among the members so the feeling of brotherhood could exist. Besides, the members also have "we-ness" feeling that enables brotherhood. In identifying ethnic groups, there are two perspectives. One, as an objective unit in term of cultural difference. Two, only a product of someone's thought that defines certain ethnic group (Abdillah, 2002).

Papua territory has various ethnics who live side by side, both from indigenous Papuan ethnics or nonPapuan ethnics. In the social life, an individual and ethnic group cannot be separated from their own inherited cultural traditions. The culture and custom is unique characteristic in the society, bureaucracy, private sector, education, and other fields. Each ethnic identity manifestation from these various ethnics are easy to identify from each living ethnic background. Therefore, this sub-chapter shall explain the involved ethnics in ethnic identity political contestation in local politics. Each indigenous ethnic in Papua has its own unique characteristic that it uses in

\section{Ethnic MT Identity Politics Manifestation}

According to Liliweri (2005), interethnic relation can happen when there is social interaction because social interaction is the beginning of social relation in social communication relation among human. This correlates with Nasdian (2015) who explained that social interaction is dynamic social relations which are; between individuals, between human groups, between individuals and human groups. The relation between MT ethnic to other ethnic such as MI, TN, $\mathrm{RA}, \mathrm{MR}, \mathrm{TA}$, and $\mathrm{AN}$ is well established.

Custom is a set of rules, values, and norms that regulate various each ethnic activities and lives. As a rule, custom is considered to be "everlasting" and it will be attaching to a person forever. From this quote, custom and culture reflected from MT ethnic characteristics are egoism, ambition, determination on every aspect such as is government, political party, and life in general.

MT ethnic identity politics manifestation is reflected on how they run government bureaucracy by using bureaucracy pathology as according to Siagian (2002) is a patronage practice. 
This practice manifests in nepotism a discrimination based on primordial bond like tribal group. MT ethnic also established an ethnic organization intended to weave harmony among themselves and also to affirm their identity politics. According to Effendi (2005), a culture to establish an organization indicates a shared belief, values, and behaviors by the entire member of the organization. MT ethnic use their organization to accommodate shared values by which they struggle in formal and non-formal institutions. Besides political organization, MT ethnic also manifest their ethnic identity politics by establishing formal organization in form of Christian church that its base members are MT ethnic. By running church organization, they strengthening their togetherness in form of family, culture, language, clan, and sameness of village from the spiritual side.

MT ethnic identity politics manifestation is by dominating government bureaucracy by using kinship culture. It is observable from same clan name of an ethnic who control head of regional government office head and secretary in available structural positions. Besides, they use their own local language while interacting to each other even when they are doing their duties in government bureaucracy. The organization they established together is operating as a communication base among themselves to the ethnic outside their group. Through the organization, they consolidate their kinship culture. They even establish Protestant Church to solidify their spiritual dimension. The church projects further their culture, language, and basic values of MT ethnic through religious hymns.

\section{Ethnic Identity Politics Manifestation}

According Walgito (1983), social psychology is relation between individuals when an individual can influence another individual in a reciprocal social interaction. Ml ethnic is Papuan ethnic who have customary land area right. Having an open-to-everyone culture, MI ethnic have never had conflict with other ethnic who live in their area. Inspired by their culture they so uphold, MI ethnic do not have any conflict with other ethnics, for example, they do not expel other ethnics who live on their soil without MI ethnic permission. They also do not hold any grudges for the fact that they are not represented in government bureaucracy and any political parties. 
MI ethnic identity politics itself unity. MI ethnic culture also apparent manifests in their positioning that from their song lyrics that use their own becomes their strategy to build and to language with the beauty of their receive trust. Meanwhile, Hasan (2015) homeland as the theme. Kind culture and explained positioning or image is not done language make ethnic MI relation to other for any attraction but rather as something Papuan ethnics and non-Papuan ethnics that is molded in prospect's mind. harmonious while living side by side on Therefore, $\mathrm{MI}$ ethnic also have an their soil. organization to bind the members, and to be the cultural and political communication channel for the members. The organization regulates rights for each members over their customary land. They also nourish their culture by holding yearly festival to celebrate the Christ's bible into their land. In the festival, they do cultural activities related to their own ethnicity such as eating sago and singing songs in their own language. Papuan ethnics are known to have their own customary lands that manifest in their own clans' surnames. Likewise, MI ethnic also have right over lands, villages, and farms that belong to them.

The conclusion is that $\mathrm{MI}$ ethnic identity politics manifestation is reflected in every activities of $\mathrm{Ml}$ ethnic members that is intended to unify themselves into ethnic collectivity (Liliweri, 2005). MI ethnic organization serves as communication hub among its ethnic members to strengthen their cultural

\section{TN Ethnic Identity Politics Manifestation}

TN ethnic also employ organization culture (Effendi, 2005) with shared values and behaviors that all the members are attached to. TN ethnic organization becomes communication hub to strengthen the brotherhood among the members. This ethnic culture is naturally hospitable that makes the relation with other ethnics is going smoothly without any significant friction.

TN ethnic identity politics is observable through TN ethnic organization that uses their own language, customary dowry, unique clan name, and the kinship solidarity. TN ethnic symbols are recognizable through its relation to other Papuan or non-Papuan ethnic groups. They weave very good relationship with existing ethnic groups.

In expressing their ethnic identity, they use formal and non-formal means. 
The formal means, for example, they record songs in their own language in cassette platform. They then distribute it to fellow ethnic members and to other ethnic groups as well. Meanwhile, in nonformal means, they communicate with fellow ethnic members to hunt in the forest.

\section{RA Ethnic Identity Politics Manifestation}

RA ethnic identity politics manifestation is visible from frequent display of culture in RA ethnic cultural festival. One of the most noticeable characteristics of RA ethnic is binds them together to work together and to help each other that has become their philosophy. RA ethnic identity politics manifestations are their language and clan's surname attached to each members. Organization culture shows the characters of an organization: shared belief, values, and behaviors among all of the organization members (Effendi, 2005).

The aforementioned organization unites RA ethnic in a cultural kinship association. Ra ethnic holds cultural festival show within which dances, music with drums and flutes are played, songs are sung in their language are displayed as unique characteristics of RA ethnic identity politics. Besides, RA ethnic also knit good relationship with Papua ethnics and non-Papua ethnics.

Bureaucracy Elites Strategy in Including Certain Ethnic into OPD Structural Positions in Government Bureaucracy

The elites have a certain strategy in making sure that only their ethnic fellows who can fill the structural positions of local government organization in the bureaucracy. The strategy is by using political lobbies among the elites in Regional Representative Assembly (DPRD), ethnic organization leaders, who previously supported and helped MR and MT ethnic in winning the first and second seat of executive positions. The elites gathered in an agreed place and all of them proposed names for representation from their respective ethnics to fill OPD structural positions to the first and second person in executive seats. They also identified political opponents from certain ethnics that must be marginalized in OPD structural positions in government bureaucracy. Of every processes negotiation with DPRD elites in filling OPD structural positions, the ethnic organization leaders return the final decision to the first and the second persons in the executive positions. It is also noteworthy that the OPD structural 
positions filling is not employing MT ethnic evidently dominate the Baperjakat and meritocratic system positions filling and followed by non(source: interview, Tuesday, 29 August Papuan ethnic such as BS, BN, MR, AN, 2017. 16:30 Eastern Indonesia Time, and TA who collaborate with MT ethnic in with Mr. HS. Vice Chairman of KS).

political agreement compared to $\mathrm{Ml}$

Ethnic identity politics has its own ethnic. The phenomenon is described in characteristics based on ethnic culture following chart. that, basically, is identity of the tribe. The According Turner (1999), ethnic characteristics are heavily organization hierarchy very much reflects influenced by certain contexts. The nature identity. Organization hierarchy implies of identity is dynamic since it is a social identity in hierarchy as different construction. Identity construction is also applied to any ethnic and community. An example of such application of ethnic identity in social life is it serves as a distinctive feature in the process of filling structural positions of OPD in government bureaucracy. It is observable from each ethnics' special features who are represented as leaders and employee's composition in government bureaucracy.

The documentation shows there has been obvious ethnic domination in holding the first seat of executive by MT ethnic since 1989 to the year of 2022. Thus, it is assured that ever since New Order era up to Reformation era, MT ethnic has been owning the regional executive seat. Similar phenomenon occurs in documented data on ethnic requires "policy" from MT and MR ethnic percentage in regional government who dominate government bureaucracy organizations (offices, bodies, districts). organizations. Non-Papuan ethnics such 
as $M R, A N$, and $T A$, and also few JA ethnic are holding positions as offices heads. One thing is confirmed that those non-Papuan ethnics who are holding the positions are generally have involved in political collaboration in supporting MT and MR ethnics in winning the first and second seats in regional executive election.

It is also very possible for relatives of MT and MR ethnics to be chosen to fill important positions. That can happen because it is impossible for both Papuan and non-Papuan ethnics to hold heads of offices, bodies, and districts without weaving a political bond in supporting MT and MR ethnics. Those important positions are not only requiring competence but also "policy" from MT and MR ethnics. The appointment of offices, bodies, and districts heads in government bureaucracy are not wholly based on capability, career, expertise, professional performance as is the case in other part of Indonesia but instead the appointment depends on the first and the second persons who are holding the executive seats.

Other documentation also shows similar pattern on positions of secretaries in offices/bodies. Most of those who sit in secretary position in offices/bodies are of
MT ethnic and non-Papuan ethnic such as BS, BN, MR, AN, and TA who collaborate with MT ethnic. The data shows there are ethnic $\mathrm{MI}, \mathrm{BK}, \mathrm{TN}$, and RA, of Papuan ethnic and non-Papuan ethnic, who are holding important positions. In general, they are politically supportive in seizing the power. The relationship between the two ethnics is getting even stronger beyond political sphere. Many of each ethnic's members are marrying each other. This social relation intensifies the political collaboration between the two. MT ethnic is the dominating Papuan ethnic in holding government bureaucracy structural positions, followed by nonPapuan ethnic, MR.

Overall, the filling of OPD structural positions which possess authority in government bureaucracy is determined by the first and second person of executive holder. The appointment is based on ethnic percentage to fill OPD structural positions of government bureaucracy, which is the policy made by the two highest rank of executive in the region. That is the context of the fact that MT ethnic is dominating every positions available in OPD structural positions of government bureaucracy, followed by non-Papuan ethnic of BS, BN, MR, AN, 
and TA who collaborate with MT ethnic to win the first seat in government bureaucracy.

On the other side, it is notable that in the officers of strategic position appointment in OPD structural government bureaucracy, friction is barely happening between MT and MI ethnic in policy implementation. It is an anomaly if this situation happens in other region. However, the empiric situation shows the conflict is almost nonexistent because there is unwritten agreement that the first and second person of highest executive rank in the region shall decide who will have positions in the government bureaucracy.

The ethnic bond in identity politics that runs in government bureaucracy is not only manifest in group of people, primordial features such as ranks, honors, language, customs laid down upon every members of the group, but also the bond expands into a characteristic that attaches to the ethnic group indicated by the growth of sense of community. Therefore, although they are not from MT ethnic, but if they have the same emotion (especially caused by marriage or kinship), according to Abdillah (2002) the emotion generates strong awareness and causes the "weness" feeling within every members.
"We" word usage in ethnic group identification has two meanings. First, as an objective unit that is interpretable as cultural characteristic difference of an individual. The "we-ness" relieves the tension in the on-going government bureaucracy. Officer appointment on strategic positions by the first and second person on the executive seats and based on kinship and ethnicity is going well. Ethnicity is a shared reality. According Abdillah (2002) the relationship is based on self-identification, and if its requirements are met there will be no ethnicity because the relationship pattern does not belong to a certain group. the relationship will be harmonious forever. Overall, the on-going identity politics practices within the government bureaucracy namely kinship, clanship, and political relation, are important and influential factors in government bureaucracy.

\section{Meritocracy Challenge vs Contested Strategic Position in Government Bureaucracy}

Ethnic identity politics contestation in the OPD structural positions based on merit system and its relation with Civil Servant Law (UU ASN) in bureaucracy. To fill structural position in government 
bureaucracy demands merit system and to get officers and apparatuses requires proper recruitment system. To get professional apparatuses, an open and competitive recruitment. The process must be open and competitive in the procedure by which officers and apparatuses who have competence, strong work commitment, and optimum performance will be selected through the procedure (Kumorotomo dan Widaningrum, 2010).

The Law No. 5 year 2014 on Civil Servant article 6 says, "Civil servant management is civil servant management to yield civil servant employees that are professional, having basic values, profession ethics, free from political intervention, free from corruption, collusion, and nepotism practices." The structural officers from echelon I, echelon II, echelon III, while regarding the existing hierarchy, propose candidates who meet the criteria to fill position vacancy to the authorized officer along with a copy directed to the Baperjakat, which is delivered to the secretary.

Indonesian government has issued related to the Law No. 52014 on Civil Servant that is closely related to merit system, which must be implemented in every part of government bureaucracy in
Republic of Indonesia. However, the irony in OPD structural positions filling in the government bureaucracy is more likely to be dominated by spoils system, patrimonialism, and ethnic identity politics of the MT ethnic and their supporting other ethnics such as BS, BN, $M R, A N$, and TA in dominating the OPD structural positions filling in government bureaucracy. Nepotism culture is still very pervasive in the government bureaucracy system (Kumorotomo and Widaningrum, 2010). The situation corresponds to what Bryant and White (in Widodo, 2008) statement that to run the duties and functions, public organization's (bureaucracy) culture emphasizes more on environment influence aspect that is deeply determining the recruitment process on bureaucracy positions. At the same time, identity politics is a leader recruitment process that tends to be based on primordialism parameter that facilitates tribalism spirit (Buchari, 2014).

The situation proves meritocracy principle related to Law on Civil Servant in government bureaucracy is not applied to assess proper officers to fill OPD structural positions in government bureaucracy. The government bureaucracy is still deeply entrenched in ethnic identity politics, spoils system, patrimonialism, and ethnic 
identity nepotism culture of MT ethnic Positions such as head of the office, along with their supporter (BS, BN, MR, secretary of the office, and other AN, TA). It is evident from the ethnic subordinate positions are being percentage in position filling in overall dominated by a system of tribalism, OPD structural position of government kinship, language oneness, that is MT bureaucracy. The established system in ethnic. The goal is to keep the economic the government bureaucracy in resource (money) for the sake of policymaking is no longer objective, individuals, group, and long-term political rational, honoring performance-based goal (local executive election/pilkada). professionalism, and career-based assessment in filling OPD structural positions in government bureaucracy. The situation creates disorganization in employee administration.

Officers in Permit Integration and Capital Investment Service Office are mostly from $\mathrm{Ml}$ ethnic, ranging from the office' head, secretary, general affair manager, finance manager, administration, and capital investment manager. They are sharing one village, one family, one language, and one ethnic, MT. The positions filling in the very strategic office is aimed to have control as much as possible over economic resource for the sake of the individuals, the group, and long-term interest.

It is conclusive from the table above that MT ethnic is dominating OPD the candidates to fill every OPD structure structural position filling in Permit in government bureaucracy, the team Integration and Capital Investment Service then recommends the name to the first Office, which is a lucrative office. and second persons in the executive to 
decide for the sake of long-term politics. privilege to the dominating ethnic in work, However, every decision made by the first is not having any trust on marginalized and the second persons in the executive do not follow any recommendations provided by the Baperjakat performance team in filling OPD structural positions in government bureaucracy. This is due to ethnic identity politics and political factors are heavily influencing the process in government bureaucracy. The situation means that the Baperjakat selection team has done their job, however, the executives disregard the recommendation in filling the OPD structural position in government bureaucracy.

Ethnic contestation dynamics in OPD structural position in government bureaucracy is very evident. The dynamics itself involves processes as follow. Political lobbies, ethnic identity identification for filling positions (head of offices and bodies, head of districts, secretary, structural positions, filling offices with plenty financial resources based on ethnicity. Ethnic contestation is also prevalent and marginalizing other Papuan ethnics in filling OPD structural positions in government bureaucracy.

Ethnic contestation is also happening in numerous activities in OPD structural positions in government bureaucracy. For example, the dominant ethnic is giving ethnic in their performance, is insisting to win every argument in every meeting, is not sharing any jobs to other ethnics, is demanding their own ethnic to predominate in every works, and is demanding to be acknowledged by other ethnics, and is marginalizing other ethnics in OPD structural positions in government bureaucracy.

The OPD structural position filling in government bureaucracy is influenced by several political actors who are suggesting and deciding the officers to appoint or to replace in ethnic contestation in filling OPD structural positions in government bureaucracy. First, ethnic organization leaders who are involved in the first and second person in executive seat election winning. These ethnic organization leaders were having political negotiation to give names of their ethnics in representing ethnic contestation in filling of OPD structural positions in government bureaucracy, or even replacing other ethnics in OPD structural positions in government bureaucracy. Second, ethnic officer actors in the government bureaucracy who directly involved in the election winning process. The supporting grounds of this strategy are at village-level 
ethnic bases in the community. The ethnic contestation in performance nor officer actors have given inputs to the first OPD structural position filling in and second persons in the executive government bureaucracy although there is seats, ethnic officer actors who support evident ethnic identity politics.

and be different in politic in first- and Furthermore, there is also second-persons election. Ethnic marginalization over both Papuan and contestation in officer appointment in non-Papuan ethnics in OPD structural OPD structural in government position filling in government bureaucracy. Third actors, first and bureaucracy. Meanwhile, personal and second persons, they who hold the power group political interests occupy DPRD. in government bureaucracy.

Ethnic organization leaders and This situation reflects that DPRD role in bureaucracy officers who support first and second persons in the executive seats are suggesting names for the executives to appoint or even to replace in filling the OPD structural positions in government bureaucracy. Finally, the executives are holding the ultimate decisions to choose the right ethnic officers to fill OPD structural positions in government bureaucracy. DPRD performance role, they never supervise nor intervene the ethnic contestation in government bureaucracy performance. They consider ethnic contestation in government supervising the ethnic contestation in government bureaucracy performance is not effective. Eventually this condition leads to poor quality of ethnic performance in government bureaucracy.

\section{CONCLUSION}

Indigenous Papuan ethnic identity politics is on the stage in contestation to seize structural positions in government bureaucracy. From the documentation data result it is evident that, in general, MT ethnic is dominating the positions of head of office, secretary, structural positions, and other strategic offices with bureaucracy performance is purely abundant financial resources. MT ethnic internal affairs of government marginalize other Papuan ethnics in head bureaucracy. DPRD recognize that all the of office or body, head of district, matters regarding the appointment is fully secretary, structural position, and they under the executive's authority. DPRD dominate the OPD structural position never supervise nor responding to any filling in government bureaucracy. 
Hometown, clan, family, kinship factors are the source of ethnic egoism that leads to certain Papuan ethnic's marginalization. Thus, other Papuan ethnics beside MT ethnic choose to collaborate with other non-Papuan ethnic to seize power in government bureaucracy. The result is that they share the OPD structural position filling in government bureaucracy. Government bureaucracy in Papua is still dominated by primordial culture such as kinship, clan, and tribe. The goal of ethnic identity politics implementation in the government bureaucracy is to control abundant economic resources such as Special Autonomy Fund, APBD, PAD, DAK, DAU, government projects and programs for the interest of their own ethnic and political groups in government bureaucracy.

Indigenous Papuan ethnic identity politics is collaborating with other nonPapuan identity politics in filling OPD structural positions in government bureaucracy. From overall percentage data of positions in OPD structural positions in government bureaucracy, MT ethnic is dominating all available positions. The following non-Papuan ethnics who are holding the positions are BS, BN, MR, AN, and TA ethnics. They are collaborating with MT ethnic to win first and second seat in the government bureaucracy. The Baperjakat team has already accomplished selection to the officers who meet the desired criteria based on their expertise, career, and professionalism according to the Law no. 5 year 2014 on Civil Servant. However, all the assessment result to appoint officers in OPD structural officers is not effectively implemented by the first and second person of the executive in the government bureaucracy. Overall, the policy in appointing officers is on the hand of the first and second person in the government bureaucracy. The goal to collaborate is to control the enormous economic resource within the government bureaucracy such as; Special Autonomy Fund, APBD, PAD, DAK, DAU, projects, and government programs for their own ethnic and political group interest.

\section{REFERENCES}

Abdillah S. Ubed. 2002. Politik Indentas Etnik, Pengulatan Tanda Tanpa Identitas. Magelang: Penerbit Indonesiatera.

Arie, M., \& Ilmar, A. (2017). The Institutional Arrangement of Special Fund Management of Papua Province. JL Poly $\&$ Globalization, 67, 79. 
Arikunto, Suharsimi, 1998. Prosedur Hasan, Ali. 2015. Tourism Marketing.

Penelitian. Rineka Cipta, Jakarta.

Bert Klandermans 2015. "Politicized Collective Identity: Collective Identity and Political Protest" In Social Identification in Groups. Published online Journal: 10 Mar 2015; 155 176.

Buchari, Sri Astuti Sri. 2014. Kebangkitan Etnik Menuju Politik Identitas. Jakarta: Yayasan Pustaka Obor Indonesia anggota IKAPI DKI.

Claude-Hélène Mayer, (2015) "Travelling inner landscapes: a longitudinal study on transcultural identity development", Equality, Diversity and Inclusion: An International Journal, Vol. 34 Issue: 4, pp. 272-292,

Effendi, Sofian. 2005. "Membangun budaya birokrasi untuk Good Governance, Lokakarya Nasional Reformasi Birokrasi". Jakarta: diselenggarakan Kantor Menteri Negara PAN, 22 September 2005.

Hapsari, Septi S. 2011. "Pemekaran

Daerah dan Penataan Birokrasi (Studi Penataan Birokrasi Dalam Konteks Pemekaran Kabupaten: Kasus Kabupaten Tambrauw Provinsi Papua Barat)". Tesis. Yogyakarta: Universita Gadjah Mada.
Yogyakarta: CAPS (Center for Academic Publishing Service).

Huntington, Samuel P. 1995. Gelombang Demokrasi Ketiga. Jakarta: Pusat Utama Grafiti, Terjemahan dari judul asli The Third Wave: Democratization.

Hong, S. (2016). Representative bureaucracy, organizational integrity, and citizen coproduction: Does an increase in police ethnic representativeness reduce crime?. Journal of Policy Analysis and Management, 35(1), 11-33.

Irawan, Prasetya. 2002. Logika dan Prosedur Penelitian. Jakarta: STIALAN Press.

Klinken, Gerry, Van. 2007. Perang Kota Kecil, Kekerasan Komunal dan Demokrasi di Indonesia. Jakarta: KTLV JI. Prapanca Raya 95 A, Kebayoran Baru 12250, Indonesia.

Kubangun I. I. 2014. "Kontestasi

Primordialisme dalam Positioning pada Struktur Birokrasi Pemerintahan Kabupaten Manokwari". Tesis. Yogyakarta: Universitas Gadjah Mada.

Kumorotomo, Wahyudi dan Widaningrum, Ambar. 2010. Reformasi Aparatur Negara Ditinjau 
Kembali. Yogyakarta: Penerbit Gava Media.

Laksono, PM., dkk. 2001. Igya Ser

Hanjop: Masyarakat Arfak dan

Konsep Konservasi. Studi Antrologi

Ekologi di Pengunungan Arfak, Irian

Jaya. Yogyakarta: KEHATI, PSAPUGM, YBLBC.

Law No. 5 year 2014 on Civil Servant

Lefaan, Avelius. 2012. "Etnosentrisme

dan Politik Representasi di Era

Otonomi Khusus Papua". Disertasi.

Yogyakarta: Universitas Gadjah

Mada. Tidak Diterbitkan.

Liliweri, Alo. 2005. Prasangka \& Konflik, Komunikasi Lintas Budaya Masyarakat Multikultur. Yogyakarta: Lkis.

Mantra, Idebagoes, 2004. Filsafat Penelitian dan Metode Penelitian Sosial. Pustaka Pertama Yogyakarta.

Mardalis, 1990. Metode Penelitian: Suatu

Pendekatan Proposal. Jakarta: Bumi Aksa Cetakan Pertama.

Moleong, Lexi, J. 1997. Metodologi Penelitian Kualitatif. Bandung: PT. Remaja Rosda Karya.

Nasdian, F.T. 2015. Sosiologi Umum. Jakarta: Yayasan Pusat Obor Indonesia.

Nasir, Moh. 1988. Metode Penelitian. Jakarta: Ghalia Indonesia.
Nawawi, H. Hadari. 2001. Metodologi Penelitian. Yogyakarta: Bidang Sosial, University Press.

Reba, Y. E., Bachri, S., Razak, A., \& Riza, M. (2015). Political-Legal Dynamics in the Establishment Status of Special Autonomy of Papua: A Historical Perspective. JL Pol'y \& Globalization, 38, 182.

Ruhyanto, A. (2016). The Perils of Prosperity Approach in Papua. Peace Review, 28(4), 490-498.

Salim, A. 2006. Teori dan Paradigma Penelitian Sosial. Yogyakarta PT. Tiara Wacana, Yogyakarta.

Siagian, P. Sondang. 2002. Manajemen Sumber Daya Manusia. Jakarta: Bumi Aksara.

Singarimbun, Masri dan Sofyan Effendi. 1995. Metode Penelitian Survei. Jakarta: LP3ES.

Sugiyono. 2007. Metode Penelitian Kuantitatif Kualitatif R \& D. Bandung: Alfabeta.

Suwae, Habel M. 2011. "Pelayanan Birokrasi Papua dalam Era Otonomi Khusus". Jurnal Dialog Kebijakan Publik Edisi 3, September 2011. HIm.11-18.

Turner, J. C. (1999). Some current issues in research on social identity and selfcategorization theories. Social 
identity: Context, commitment, content, 3(1), 6-34.

Widodo, Joko. 2008. Membangun

Birokrasi Berdasarkan Kinerja.

Cetakan Keempat. Malang:

Bayumendia Publishing. 